\title{
Corporate financial structure of South Korea after Asian financial crisis: the chaebol experience
}

Jiyoung $\mathrm{Kim}^{*}$ (1)

*Correspondence:

jiyoung_kim@ide.go.jp Global Value Chains Studies

Group, Inter-disciplinary

Studies Center, Institute

of Developing Economies,

Japan External Trade

Organization (IDE-JETRO),

Chiba, Japan

\begin{abstract}
The chaebol, a South Korean form of business conglomerate, has been a key factor in the country's economic growth. In this study, the chaebol sector is added to the assetliability matrix derived from a flow-of-funds analysis in order to explain the role of the chaebol in the Korean financial system. We find that the power-of-dispersion indices in the asset-oriented system differ between the chaebol and other private corporations. Between 1987 and 2002, the former has increased while the latter has declined. In the case of the chaebol, excess liabilities were reduced, while investments in financial assets were increased. This tendency led to an increase in the power-of-dispersion index in this asset-oriented system. Our previous research found a decrease in this index for the private sector in Korea. However, the index increased for chaebo/ when the private sector is divided into the chaebol and small-/medium-sized corporations in this paper. These results point to a greater concentration of economic power in the chaebol in the Korean financial market.
\end{abstract}

Keywords: Flow-of-funds analysis, Asset-liability matrix, Financial conglomerates (chaebol)

JEL Classification: G30, O16, C67, O53, N25

\section{Background}

The chaebol, a South Korean form of business conglomerate, has been a key factor in the country's economic growth. In general, a group of large-scale, family-run management enterprises is referred to as a chaebol. Jones and Sakong (1980) defined a chaebol as the Korean term for a conglomerate of many companies clustered and managed by one family-centered parent company. The characteristics of a chaebol are similar to those of the zaibatsu of pre-war Japan. According to Kim (2000), the ratio of capital to bank loans of chaebol is higher than that of the pre-war zaibatsu.

The birth of the chaebol dates back to the 1950s or earlier in Korea. However, it was not until the early 1980s that they emerged as entities that enjoyed a monopolistic concentration of capital. Many firms appeared in Korea in the 1950s, with some of them accumulating a huge influx of wealth. The chaebol were formed during the rule of Syngman Rhee, supported by the sale of property formerly owned by the colonial Japanese government, foreign aid, and an import-substitution industrialization policy (Choi 2007). When Park Chung-hee came to power in 1961, a policy of industrialization and

(c) The Author(s) 2017. This article is distributed under the terms of the Creative Commons Attribution 4.0 International License (http://creativecommons.org/licenses/by/4.0/), which permits unrestricted use, distribution, and reproduction in any medium, provided you give appropriate credit to the original author(s) and the source, provide a link to the Creative Commons license, and indicate if changes were made. 
financial support contributed to the advancement of the Korean chaebol system (Amsden 1989). Moreover, in the 1980s, the chaebol wanted a more liberal financial system that would allow greater control over capital and investment. At the same time, they also wanted the system to remain protected to the extent that it provided them with cheap credit (Amsden and Euh 1992). According to Lee et al. (2002), the top 30 chaebol owned 12 security companies (out of a total of 25), 18 insurance companies (out of a total of 35) and 18 investment trust companies (out of a total of 38) in 1988. The chaebol became less dependent on government-controlled commercial banks, while the government lost much of its power to influence the chaebol's investment decisions.

Many researchers have pointed out that the Korean government's policy on interest rates and financial activities led to the concentration of economic power in the chaebol. According to (Lee 2002), during the 1980s and 1990s, the top 30 chaebol accounted for more than one-third of the nation's industrial output. In particular, they ran non-banking financial companies themselves, using them as a tool to raise capital. This enabled the chaebol to raise money on their own in spite of government restrictions on the total amount of loans and credit that a bank could extend to the chaebol. Krueger et al. (2002) estimated asset growth rates of the Big 5 and Big 30 chaebol and the total manufacturing sector from 1985 to 1999 . They argued that the growth of chaebol assets has been much more rapid than that of non-chaebol firms. However, most research has focused on the financial structure of the chaebol or on a comparative analysis of the large and small- $/$ medium-sized corporations. Unfortunately, some research was not based on logical analysis due to a lack of data. It is difficult to quantify the effects or interactions between the chaebol and other sectors in the financial system, such as banks, the government, and households.

This paper analyzes the chaebol using flow-of-funds (FOF) accounts. The FOF accounts consist of the balance sheets of all institutional sectors in a country, including the foreign sector. The FOF table shows the interrelations between various institutional sectors. In this analysis, we integrate the chaebol into FOF accounts. Applying the inputoutput analysis method to FOF accounts, $Y$ and $Y^{*}$ matrices (asset-liability matrix of institutional sector-by-institutional sector) are obtained. Furthermore, using a Leontief inverse matrix, four kinds of indices (the power-of-dispersion index and the sensitivityof-dispersion index) are estimated. Some previous studies attempted to subdivide the corporate sector of the FOF accounts into various industries. For example, Nishiyama (1991) used the balance sheets and income statements of each industry in Japan to subdivide non-financial corporations in FOF accounts into 37 industries. In this paper, the power indices of 44 institutional sectors are reported. Kim (2016) used this method to disaggregate the Korean FOF accounts into 115 institutional sectors, including 95 types of inter-industries, combined with the Financial Statement Analysis data. According to these studies, using balance sheets and income statement data for each industry, it is possible to generate expanded FOF accounts that indicate the financial transactions of each industry. Therefore, if the financial statements of the chaebol are obtained, then it will be possible to add the chaebol sector to the FOF account. This research aims to find and identify the characteristics and roles of the chaebol in the financial system of Korea. This paper consists of four sections. The first section is the introduction. The second section explains the data and the analytical method adopted in this study. The third section 
describes the results of our research in three parts. Conclusions are drawn in the last section.

\section{Data and research methods}

\subsection{Data}

For the purpose of analysis, the FOF accounts and chaebol balance sheets are used. Since the data in the Korean FOF accounts in the 1993 SNA are only available back to 2002, I decided to adopt the FOF accounts in the 1968 SNA, which are composed of nine institutional sectors and available from 1975 to 2005. By using the chaebol's balance sheets, Korean corporations can be classified into two categories: the "chaebol" and "other private corporations." The volume of financial transactions by other private corporations is calculated by subtracting chaebol entries from the balance sheets. This study uses balance sheets for the top 30 chaebol compiled through collaboration with the Institute for Participatory Society and the Institute of Business and Economic Research (IBER) of Inha University ${ }^{1}$ These balance sheets are available from 1987 to 2002. Table 1 shows a list of the top 30 chaebol used in this paper. We will focus our analysis on data from the years 1987, 1992, 1997, and 2002. Data for 1998, one year after the Asian financial crisis, were also added to the analysis. Table 1 shows the list of the top 30 chaebol for each year.

\subsection{Reconstruction of FOF tables}

The FOF table shows the interrelations between the various institutional sectors in a systematic and coherent way. The FOF system adopts the quadruple-entry system proposed by Copeland (1952), in which each transaction is recorded with a double entry. While the FOF table, which is published by the Bank of Korea (2001), contains only financial assets and liabilities, the chaebol balance sheets include real assets and liabilities as well. By referencing a guide to writing FOF tables and the Bank of Korea Web site, only the items used in FOF accounts are selected from the chaebol balance sheets. Based on the selected items, the institutional sector of private corporations in the FOF table is broken down into two sections, eventually creating 10 subsections. We can also reconstruct the FOF table for each year, which is reflected in the chaebol balance sheets.

\subsection{Methodologies}

In this analysis, I will apply the input-output analysis method devised by Tsujimura and Mizoshita (Tsujimura and Masako 2002a, b) ${ }^{2}$ to the FOF accounts. The Bank of Korea publishes quarterly and yearly FOF accounts for Korea which contain (1) financial transactions (flows) and (2) financial assets and liabilities (stocks). The asset-liability matrix used in this paper has been compiled from the financial asset and liability tables of the annual FOF accounts.

First, the procedure requires the construction of two tables $E$ and $R$. Table $E$ is a matrix representing the fund-employment portfolio of each institutional sector, while the table $R$ shows the fund-raising of each institutional sector. By applying the method widely used in input-output analysis, it is possible to make two types of square matrices $Y$ and

\footnotetext{
${ }^{1}$ Refer to Appendix of Lee (2005).

${ }^{2}$ For details, see Tsujimura and Mizoshita (2002a, 2003) in English and Tsujimura and Mizoshita (2002b), pp. 32-43 and pp. 116-129 in Japanese.
} 
Table 1 Top 30 chaebol

\begin{tabular}{|c|c|c|c|c|c|}
\hline & 1987 & 1992 & 1997 & 1998 & 2002 \\
\hline 1 & Hyundai & Hyundai & Hyundai & Hyundai & Samsung \\
\hline 2 & Daewoo & Samsung & Samsung & Daewoo & LG \\
\hline 3 & $\mathrm{LG}$ & Daewoo & Daewoo & Samsung & SK \\
\hline 4 & Samsung & $\mathrm{LG}$ & $L G$ & LG & $\begin{array}{l}\text { Hyundai Motor } \\
\text { Group }\end{array}$ \\
\hline 5 & Hanjin & SK & SK & SK & Hanjin \\
\hline 6 & Ssangyong & Hanjin & Hanjin & Hanjin & Lotte \\
\hline 7 & SK & Ssangyong & Ssangyong & Ssangyong & Hyundai \\
\hline 8 & Hanwha & $\mathrm{KIA}$ & Hanwha & Hanwha & Kumho \\
\hline 9 & Lotte & Hanwha & Kumho & Kumho & $\begin{array}{l}\text { Hyundai Heavy } \\
\text { Industries Group }\end{array}$ \\
\hline 10 & $\mathrm{KIA}$ & Lotte & Donga & Lotte & Hanwha \\
\hline 11 & Daelim & Kumho & Lotte & Donga & Doosan \\
\hline 12 & Donga & Daelim & Halla & Hansol & Dongbu \\
\hline 13 & Hanil & Doosan & Daelim & Doosan & Hyundai Oil \\
\hline 14 & Hyosung & Donga & Doosan & Daelim & Hyosung \\
\hline 15 & Doosan & Hanil & Hansol & $\begin{array}{l}\text { Dongkuk Steel } \\
\text { Group }\end{array}$ & Daelim \\
\hline 16 & $\begin{array}{l}\text { Dongkuk Steel } \\
\text { Group }\end{array}$ & Hyosung & Hyosung & Dongbu & Kolon \\
\hline 17 & $\begin{array}{l}\text { Pan Ocean } \\
\text { Shipping }\end{array}$ & $\begin{array}{l}\text { Dongkuk Steel } \\
\text { Goup }\end{array}$ & Kohap & Halla & CJ \\
\hline 18 & Kolon & Halla & Kolon & Kohap & $\begin{array}{l}\text { Dongkuk Steel } \\
\text { Group }\end{array}$ \\
\hline 19 & Kumho & Tongyang & $\begin{array}{l}\text { Dongkuk Steel } \\
\text { Goup }\end{array}$ & Hyosung & Hanaro Telecom \\
\hline 20 & Kukdong $\mathrm{E}$ and $\mathrm{C}$ & Kolon & Dongbu & Kolon & Hansol \\
\hline 21 & Dongbu & Jinro & Anam & Tongyang & Shinsegye \\
\hline 22 & $\begin{array}{l}\text { Woo Sung } \\
\text { Construction }\end{array}$ & Dongbu & Jinro & Jinro & Tongyang \\
\hline 23 & Kohap & Kohap & Tongyang & Anam & $\begin{array}{l}\text { Hyundai Depart- } \\
\text { ment Store }\end{array}$ \\
\hline 24 & Haitai & Kukdong $\mathrm{E}$ and $\mathrm{C}$ & Haitai & Haitai & $\begin{array}{l}\text { Hyundai Develop- } \\
\text { ment }\end{array}$ \\
\hline 25 & Tongil & $\begin{array}{l}\text { Woo Sung Con- } \\
\text { struction }\end{array}$ & Shinho & Saehan & Youngpoong \\
\hline 26 & Daesang & Haitai & Daesang & Kangwon Industry & Daesang \\
\hline 27 & Taekwang & Byucksan & Newcore & Daesang & Dongwon \\
\hline 28 & Kangwon Industry & Daesang & Geopyeong & CJ Cheiljedang & $\begin{array}{l}\text { Taekwang Industrial } \\
\text { Co. }\end{array}$ \\
\hline 29 & Samwhan & Anam & Kangwon Industry & Shinho & KCC \\
\hline 30 & Shindonga & Hanbo & Saehan & Samyang & $\begin{array}{l}\text { Oriental Chemical } \\
\text { Industries Group }\end{array}$ \\
\hline
\end{tabular}

$Y^{*}$, using tables $E$ and $R$. Table $Y$ is based on a fund-employment portfolio, while $Y^{*}$ is founded on a fund-raising portfolio.

In the liability-oriented system, matrices $B$ and $D$ are expressed as follows:

$$
\begin{aligned}
& b_{i j}=r_{i j} / t_{j} \\
& d_{i j}=e_{i j}^{\prime} / t_{j}^{E}
\end{aligned}
$$


where $t_{j}$ vector represents the sum of either assets or liabilities whichever is greater and $t_{j}^{E}$ means the sum of assets. In the same manner, matrices $B^{*}$ and $D^{*}$ of the asset-oriented system are defined as follows:

$$
\begin{aligned}
& b_{i j}^{*}=e_{i j} / t_{j} \\
& d_{i j}^{*}=r_{i j}^{\prime} / t_{j}^{R}
\end{aligned}
$$

where $t_{j}^{R}$ means the sum of liabilities. The $m \times m$ ( $m$ : number of institutional sectors) coefficient matrices $C$ and $C^{*}$ are estimated using the institutional sector portfolio assumption.

$$
\begin{aligned}
& C=D B \\
& C^{*}=D^{*} B^{*}
\end{aligned}
$$

Each element of the transaction quantity matrices $Y$ and $Y^{*}$ is then obtained as follows:

$$
\begin{aligned}
y_{i j} & =c_{i j} t_{j} \\
\mathrm{y}_{i j}^{*} & =\mathrm{c}_{i j}^{*} t_{j}
\end{aligned}
$$

$y_{i j}$ is the amount of funds provided from the $i$ th to $j$ th institutional sector, and $y_{i j}^{*}$ is the amount of funds from the $j$ th to $i$ th institutional sector.

Next, we apply the Leontief Inverse to obtain the indices of the power and the sensitivity of dispersion to the asset-liability matrix. Table $Y$ can be represented in matrix terms as follows, where $\varepsilon^{Y}$ means excess liabilities.

$$
C T^{Y}+\varepsilon^{Y}=T^{Y}
$$

Solving each equation for $T^{Y}$ yields

$$
\begin{aligned}
& T^{Y}=(I-C)^{-1} \varepsilon^{Y} \\
& T^{Y}=I \varepsilon^{Y}+C \varepsilon^{Y}+C^{2} \varepsilon^{Y}+C^{3} \varepsilon^{Y}+\cdots
\end{aligned}
$$

where $I$ denotes the $m \times m$ unit matrix and $(I-C)^{-1}$ is Leontief inverse matrix. Matrix $\Gamma$ is expressed as follows:

$$
\Gamma=(I-C)^{-1}=\left[\begin{array}{cccc}
\gamma_{11} & \gamma_{12} & \cdots & \gamma_{1 m} \\
\gamma_{21} & \gamma_{22} & \cdots & \gamma_{2 m} \\
\vdots & \vdots & \ddots & \vdots \\
\gamma_{m 1} & \gamma_{m 2} & \cdots & \gamma_{m m}
\end{array}\right]
$$

Using $\gamma_{i j}$, it is possible to calculate indices for both power-of-dispersion and sensitivityof-dispersion in the liability-oriented system. The power-of-dispersion index $\omega_{j}^{Y}$ and the sensitivity-of-dispersion index $z_{i}^{Y}$ are defined as follows.

$$
\omega_{j}^{Y}=\frac{\sum_{i=1}^{m} \gamma_{i j}}{\frac{1}{m} \sum_{j=1}^{m} \sum_{i=1}^{m} \gamma_{i j}}
$$




$$
z_{i}^{Y}=\frac{\sum_{j=1}^{m} \gamma_{i j}}{\frac{1}{m} \sum_{i=1}^{m} \sum_{j=1}^{m} \gamma_{i j}}
$$

Using the same method as in $Y^{*}$, we can also estimate the power-of-dispersion index $\omega_{j}^{Y^{*}}$ and the sensitivity-of-dispersion index $\mathrm{z}_{\mathrm{i}}^{\mathrm{Y}^{*}}$ in the asset-oriented system.

The power-of-dispersion index in the liability-oriented system describes the relative extent to which a unit increase in demand for capital of a given institutional sector is dispersed throughout the financial system. The power-of-dispersion index in the asset-oriented system measures the increase in the final supply to the system of industries in general as driven by a unit increase in the capital supply of a given institutional sector. The sensitivity-of-dispersion index in the liability-oriented system measures the amount of funds which can be raised in a given institutional sector, directly or indirectly driven by a unit increase in the final borrowing for all institutional sectors in the system. Meanwhile, the sensitivity-of-dispersion index in the asset-oriented system describes the extent to which money can be supplied to a given institutional sector, directly or indirectly driven by a unit increase in the final lending for all institutional sectors in the system.

\section{Results}

\subsection{Liability portfolios of corporations}

First, we begin by using this section to analyze the financial structures of the chaebol. Tables 2 and 3 show the liabilities of the top 30 chaebol. In Table 2, the total liabilities peaked in 1997 during the Korean economic crisis. The debt ratio of the chaebol shown

Table 2 Liabilities of the chaebol (using table $R$, in Bil. KRW)

\begin{tabular}{|c|c|c|c|c|c|}
\hline & 1987 & 1992 & 1997 & 1998 & 2002 \\
\hline Securities & 15930.9 & 52049.2 & 119552.3 & 157520.3 & 106441.8 \\
\hline Commercial papers & 2530.5 & 10040.5 & 19645.4 & 16393.8 & 2192.4 \\
\hline Corporate bonds (including current portion) & 5570.7 & 24811.2 & 71549.6 & 106803.7 & 58705.8 \\
\hline Current portion of bonds & 1181.5 & 8260.6 & 16223.9 & 23465.7 & 17380.9 \\
\hline Corporate bonds & 4389.2 & 16550.5 & 55325.7 & 83338.1 & 41324.9 \\
\hline Stocks & 7829.8 & 17197.5 & 28357.3 & 34322.8 & 45543.7 \\
\hline Loans and foreign aid & 25839.7 & 51141.4 & 147605 & 116451.4 & 38105.8 \\
\hline Loans (KRW) & 18215.2 & 35639.9 & 90371.1 & 84779.9 & 25915.2 \\
\hline Short-term loans & 9358.8 & 20458.2 & 58034.4 & 48598.1 & 10062.3 \\
\hline Long-term loans (including current portion) & 8856.3 & 15181.6 & 32336.6 & 36181.7 & 15852.9 \\
\hline Current portion of long-term loans & 984.8 & 2633.5 & 6842.5 & 8196.1 & 4301.7 \\
\hline Long-term loans & 7871.5 & 12548.1 & 25494.1 & 27985.6 & 11551.2 \\
\hline Loans (foreign currency and foreign aid) & 7624.5 & 15501.6 & 57233.9 & 31671.5 & 12190.6 \\
\hline Short-term loans & 1025.8 & 4582.1 & 19863.5 & 10733 & 7742.6 \\
\hline Long-term loans (including current portion) & 6327.5 & 10901.5 & 37370.4 & 20746.8 & 4448 \\
\hline Current portion of long-term loans & 1083.8 & 2187.3 & 6319.7 & 4666.8 & 1574.1 \\
\hline Long-term loans & 5243.7 & 8714.2 & 31050.7 & 16080 & 2873.9 \\
\hline Foreign aid & 271.2 & 18 & 0 & 191.7 & 0 \\
\hline Trade credits & 7512 & 21196.9 & 50223.5 & 42709.3 & 45004.6 \\
\hline Others & 5612.2 & 15816.3 & 34843.7 & 33720.2 & 36339.4 \\
\hline Total & 54894.9 & 140203.8 & 352224.5 & 350401.1 & 225891.6 \\
\hline
\end{tabular}


Table 3 Liabilities of the chaebol (in percentage)

\begin{tabular}{lrrrrr}
\hline & $\mathbf{1 9 8 7}(\mathbf{\%})$ & $\mathbf{1 9 9 2}(\%)$ & $\mathbf{1 9 9 7}(\%)$ & $\mathbf{1 9 9 8}(\%)$ & $\mathbf{2 0 0 2}$ (\%) \\
\hline Securities & 29.0 & 37.1 & 33.9 & 45.0 & 47.1 \\
Commercial papers & 4.6 & 7.2 & 5.6 & 4.7 & 1.0 \\
Corporate bonds (including current portion) & 10.1 & 17.7 & 20.3 & 30.5 & 26.0 \\
Current portion of bonds & 2.2 & 5.9 & 4.6 & 6.7 & 7.7 \\
Corporate bonds & 8.0 & 11.8 & 15.7 & 23.8 & 18.3 \\
Stocks & 14.3 & 12.3 & 8.1 & 9.8 & 20.2 \\
Loans and foreign aid & 47.1 & 36.5 & 41.9 & 33.2 & 16.9 \\
Loans (KRW) & 33.2 & 25.4 & 25.7 & 24.2 & 11.5 \\
Short-term loans & 17.0 & 14.6 & 16.5 & 13.9 & 4.5 \\
Long-term loans (including current portion) & 16.1 & 10.8 & 9.2 & 10.3 & 7.0 \\
Current portion of long-term loans & 1.8 & 1.9 & 1.9 & 2.3 & 1.9 \\
Long-term loans & 14.3 & 8.9 & 7.2 & 8.0 & 5.1 \\
Loans (foreign currency and foreign aid) & 13.9 & 11.1 & 16.2 & 9.0 & 5.4 \\
Short-term loans & 1.9 & 3.3 & 5.6 & 3.1 & 3.4 \\
Long-term loans (including current portion) & 11.5 & 7.8 & 10.6 & 5.9 & 2.0 \\
$\quad$ Current portion of long-term loans & 2.0 & 1.6 & 1.8 & 1.3 & 0.7 \\
Long-term loans & 9.6 & 6.2 & 8.8 & 4.6 & 1.3 \\
Foreign aid & 0.5 & 0.0 & 0.0 & 0.1 & 0.0 \\
Trade credits & 13.7 & 15.1 & 14.3 & 12.2 & 19.9 \\
Others & 10.2 & 11.3 & 9.9 & 9.6 & 16.1 \\
Total & 100.0 & 100.0 & 100.0 & 100.0 & 100.0 \\
\hline
\end{tabular}

in Table 3 reveals that the ratio of marketable securities they hold rose from $29.0 \%$ in 1987 to $47.1 \%$ in 2002 . This indicates a shift from indirect to direct financing. The ratio of stocks had fallen from $14.3 \%$ in 1987 to $8.1 \%$ in 1997 , a clear indicator that they had difficulty raising money from the stock market during the financial crisis. The ratio of corporate bonds soared from $10.1 \%$ in 1997 to $30.5 \%$ in 1998. Meanwhile, the ratio of loans, an indirect fund-raising method, fell from $47.1 \%$ in 1987 to $16.9 \%$ in 2002.

Table 4 shows the liability portfolios of the chaebol and other private corporations created using table $Y$. As shown in Table 3, the chaebol borrowed $21.9 \%$ of their money from other financial institutions and 21.2\% from banks in 1987. However, in the 1990s, loans from banks fell to $17.9 \%$ while those from other financial institutions rose to $31.7 \%$ in 1998. Corporations other than the chaebol show a similar trend in financing sources as the chaebol. However, we find that the ratio of fund-raising from banks by other private corporations rose to $28.1 \%$ in 2002 . Another contrast between the two entities can be observed in the way they raise funds through subsidiaries. To overcome the global financial crisis, the chaebol increased dependence on their subsidiaries for funding, with these arrangements making up $14.6 \%$ of liabilities in 1997 and $12.9 \%$ in 1998 . This is a trend not observed in other private corporations. It is noteworthy that the chaebol's funding from other private corporations rose to $16.7 \%$ in 2002. In the 2000 s, the lending of other financial institutions to the chaebol fell while the flow of capital from other private corporations to the business conglomerates increased. Such diversification of funding sources is not seen in corporations other than the chaebol. Other private corporations showed a reliance on banks and other financial institutions for funding. 


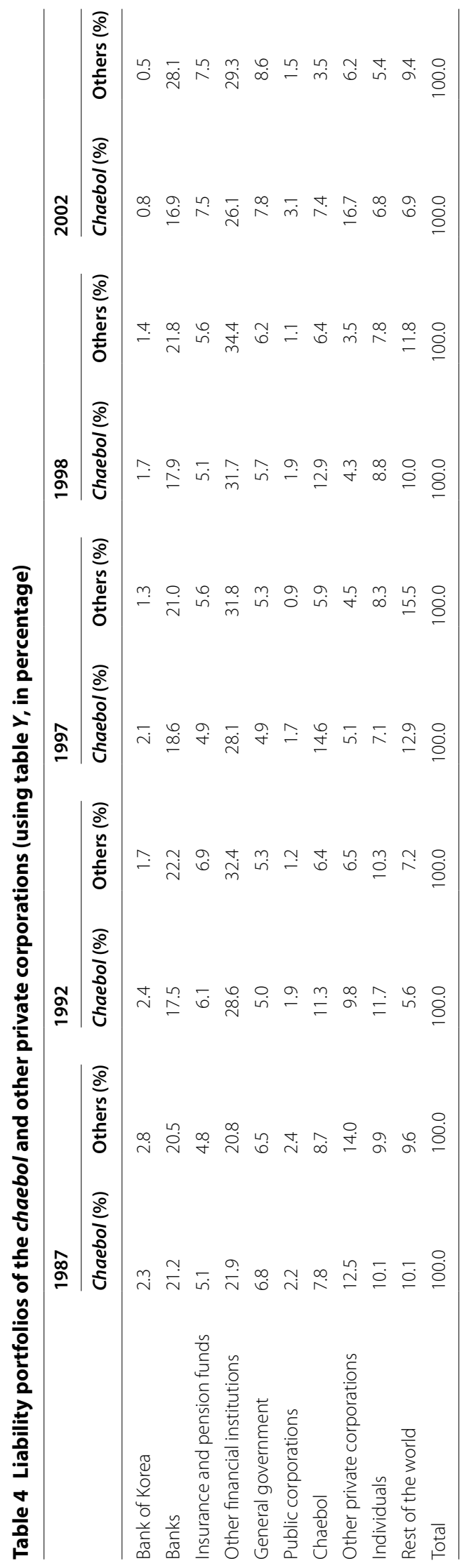




\subsection{Power-of-dispersion index and sensitivity-of-dispersion index analysis}

Figures 1 and 2 show the power-of-dispersion index and the sensitivity-of-dispersion index for the different institutional sectors. The baseline for the index used to measure the extent of dispersion is one. The major benefit of these indices is that they enable identification of the relative position of each institutional sector in the financial market where the institutional sectors are interdependent on one another in a direct or indirect way. The power-of-dispersion index in the liability-oriented system is shown in the rows while the power-of-dispersion index in the asset-oriented system is shown in
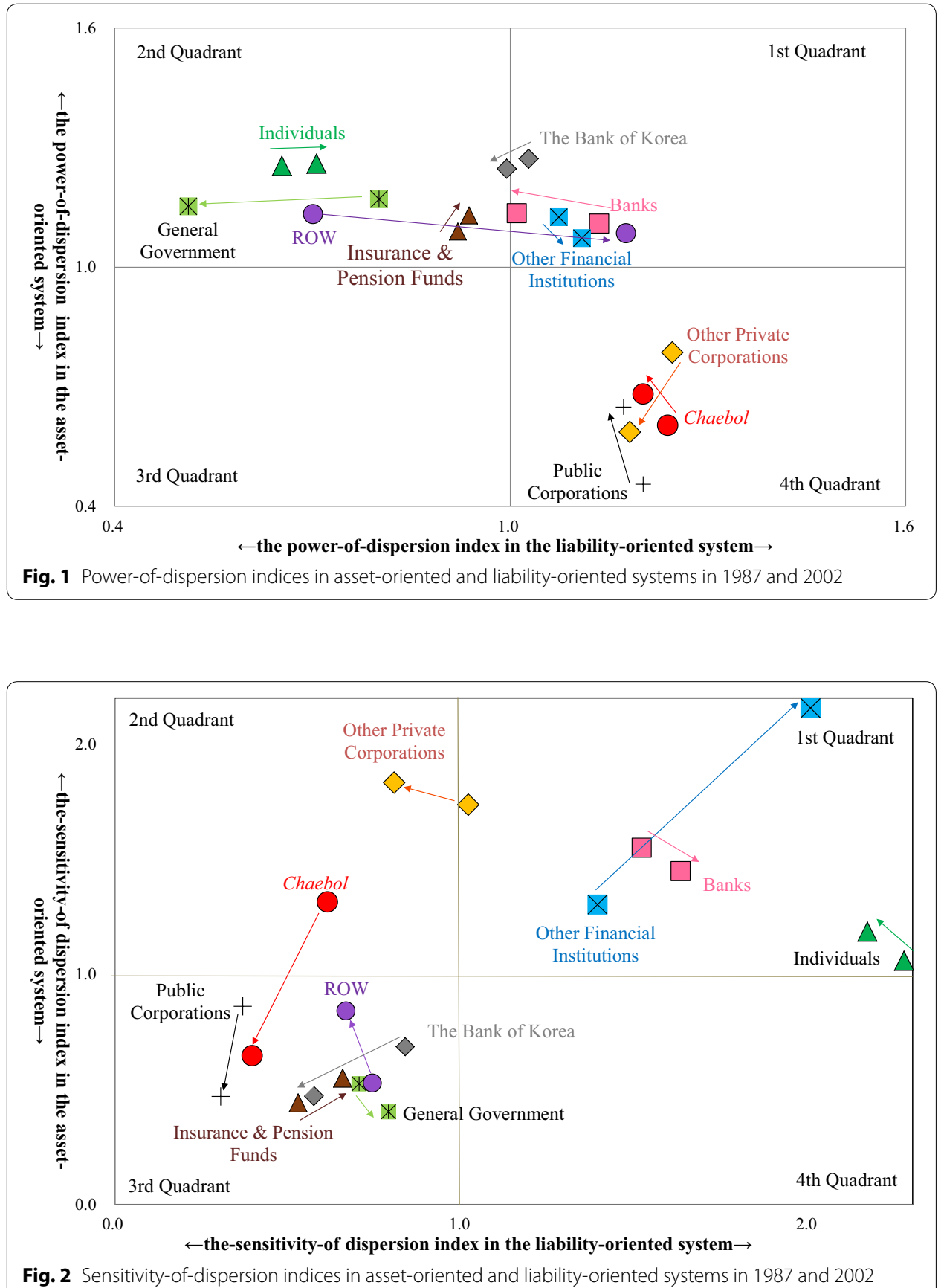
the columns. Each institutional sector is placed in a four-quadrant graph. For example, households with excess savings are generally located in the second quadrant because they exercise more power over assets and less power over liabilities. Meanwhile, corporations with excess investment are placed in the fourth quadrant because they hold more power over liabilities and less power over assets.

Figure 1 shows the relations between the power-of-dispersion index in the liabilityoriented system and the one in the asset-oriented system in 1987 and 2002. In 1987, the Bank of Korea, banks, and other financial institutions were located in the first quadrant. Individuals (most of them households), general government, and insurance and pension funds belonged to the second quadrant. All corporations and the rest of the world (overseas sector) were placed in the fourth quadrant. The Bank of Korea and the overseas sector shifted to the fourth quadrant in 1997 and the first quadrant in 1998.

Figure 2 shows the sensitivity-of-dispersion index in the liability-oriented and assetoriented systems. Unlike in the case of the power-of-dispersion index, corporations and individuals are expected to be in the second and fourth quadrant, respectively. In 1987, the Bank of Korea, insurance and pension funds, public corporations, and the overseas sector stayed in the third quadrant, showing a neutral trend. Banks, a classic example of a financial intermediary, and other financial institutions are located in the first quadrant while the chaebol belong in the second quadrant. One thing to note is that, contrary to expectations, other private corporations and individuals belong to the first quadrant. Based on the data from 2000, Tsujimura and Mizoshita (2002b) demonstrated that Japanese households were located in the first quadrant. This reflects how households, characterized by excess savings, have invested in assets such as houses. We also observe a shift in the sensitivity-of-dispersion index for corporations, when private corporations moved to the second quadrant in the 1990s while the chaebol shifted to the third quadrant in 2002 .

For corporations, all indices shifted with the exception of the power-of-dispersion index in the liability-oriented system, which stayed at the 1.2 level during this period. Both the chaebol and other private corporations show a downward trend in the sensitivity-of-dispersion index in the liability-oriented system. In the power-of-dispersion index in the asset-oriented system, the chaebol recorded 0.6 in 1987 with the figure rising to 0.68 in 2002. By contrast, the figure for private corporations fell from 0.79 to 0.59 during the same period. In the sensitivity-of-dispersion index in the asset-oriented system, the chaebol remained at 1.3 until the 1990s when the figure fell to 0.65 in 2002 . This figure rose to 1.83 in 2002 for other corporations.

\subsection{Asset portfolios of corporations}

In the previous section, we showed that for chaebol the power index in the asset-oriented system rose from 1987 to 2002. In contrast, the index fell for other private corporations during that period. In our previous study, Kim (2013) estimated the power-of-dispersion index of private corporations in Korea and Japan from the 1970s until 2012. According to this comparative analysis, the power index in the asset-oriented system of private corporations has steadily increased in Japan, finally exceeding stand$\operatorname{ards}^{3}$ after 2010. In contrast, the power index of private corporations has fallen in Korea.

${ }^{3}$ The index is standardized by 1 . 
Going one step further, we divided private corporations between the chaebol and other private corporations in Korea. The decreasing tendency of the power index in the assetoriented system of Korean private corporations is caused by characteristics of other private corporations. The power index of the chaebol had grown until 2002. In Japan, we find that private corporations have reduced investment in equipment and focused instead on financial investment, giving rise to the increase in the power index in the asset-oriented system.

Let us put this into perspective by looking at the financial asset ratio of the chaebol in Table 5. In 1997, marketable securities accounted for less than $20 \%$ of their total assets, but in 2002 this figure had risen to $54.4 \%$. By contrast, trade credits represented more than $40 \%$ of assets until the end of the 1990s, falling to $17.4 \%$ in 2002. Table 6 shows that the asset portfolios of the chaebol shifted dramatically to other financial institutions. A previous study by Lee (2002) concluded that the chaebol found it easier to borrow money from banks in the 1980s, in contrast to the past when their major source of capital was the non-banking sector. In our study, we find that they invested more actively in non-banking financial institutions in the 2000s.

On the other hand, the real asset term is obtained by subtracting total financial assets from total liabilities. Real assets are composed of inventories, tangible assets, and intangible assets in chaebol data. Finished or semi-finished goods, raw materials, and other inventories are included in these inventories. Land, buildings and structures, machinery and equipment, ship vehicles and transportation equipment, construction in progress,

Table 5 Financial assets of the chaebol (using table $E$, in percentage)

\begin{tabular}{lccccc}
\hline & $\mathbf{1 9 8 7}(\%)$ & $\mathbf{1 9 9 2}(\%)$ & $\mathbf{1 9 9 7}(\%)$ & $\mathbf{1 9 9 8}(\%)$ & $\mathbf{2 0 0 2}(\%)$ \\
\hline Currency & 0.3 & 0.1 & 0.0 & 0.0 & 0.0 \\
Deposits & 13.7 & 16.7 & 11.6 & 4.0 & 0.5 \\
Securities & 18.6 & 19.4 & 19.7 & 34.2 & 54.4 \\
Trade credits & 42.8 & 43.8 & 47.9 & 41.3 & 17.4 \\
Loans & 1.2 & 0.2 & 0.4 & 1.3 & 6.3 \\
Others & 23.4 & 19.9 & 20.4 & 19.3 & 21.3 \\
Total & 100.0 & 100.0 & 100.0 & 100.0 & 100.0 \\
\hline
\end{tabular}

Table 6 Financial asset portfolios of the chaebol (using table $Y$, in percentage)

\begin{tabular}{|c|c|c|c|c|c|}
\hline & $1987(\%)$ & $1992(\%)$ & $1997(\%)$ & $1998(\%)$ & $2002(\%)$ \\
\hline Bank of Korea & 2.7 & 2.5 & 1.2 & 2.4 & 4.6 \\
\hline Banks & 14.1 & 13.0 & 11.7 & 7.9 & 7.2 \\
\hline Insurance and pension funds & 1.1 & 1.3 & 1.6 & 1.8 & 3.1 \\
\hline Other financial institutions & 14.6 & 19.9 & 17.5 & 20.6 & 29.6 \\
\hline General government & 1.1 & 0.8 & 1.0 & 1.8 & 3.9 \\
\hline Public corporations & 8.1 & 6.0 & 5.5 & 6.3 & 5.4 \\
\hline Chaebol & 18.4 & 25.2 & 30.4 & 28.1 & 13.4 \\
\hline Other private corporations & 28.1 & 18.6 & 16.6 & 18.4 & 23.5 \\
\hline Individuals & 11.6 & 12.6 & 13.9 & 11.9 & 7.6 \\
\hline Rest of the world & 0.2 & 0.1 & 0.6 & 0.9 & 1.8 \\
\hline Total & 100.0 & 100.0 & 100.0 & 100.0 & 100.0 \\
\hline
\end{tabular}


and other tangible assets are considered tangible assets. Lastly, intangible assets contain development costs and the like. Table 7 represents the component ratio of real assets. The real asset term is composed of $26.6 \%$ inventories, $72.3 \%$ tangible assets, and $1.1 \%$ intangible assets in 1987. The ratio of inventories had steadily declined, and finally fell to $12.1 \%$ in 2002 . In contrast, tangible and intangible assets had increased. Especially, growth of land and intangible assets are significant.

\section{Concluding remarks}

This research examined FOF analysis by adding the chaebol sector to asset-liability matrix with the goal of discovering the role of the chaebol in the financial system of Korea. Using FOF accounts and the balance sheets of the top 30 chaebol, we divided the private corporate sector into chaebol and other private corporations. We obtained new asset-liability matrices for the private corporate sector which were then restructured and analyzed in order to discover the characteristics of the chaebol and other private corporations during the past 15 years.

The chaebol of Korea, which appeared in the 1950s, rapidly accumulated wealth through foreign aid and government property transfers to private ownership. Under Park, who came to power in the 1960s, the chaebol dominated the product market of Korea, assisted by heavy and chemical industry policy and an import-substitution industrialization policy. The government intensively supported the chaebol in order to raise the competitiveness of Korean corporations in the international market. Furthermore, the financial liberalization policy of the 1980s helped the chaebol to enter the financial market. The chaebol expanded to the non-banking sector immediately, prompted by deregulation of non-bank depository institutions and the privatization of some government-owned banks. Through financial liberalization and the growth of the stock market, the fund-raising strategy of the chaebol changed from indirect to direct. This has been noted in previous research and is also found in the FOF accounts used in this analysis, which are composed of only financial items.

It is no exaggeration to say that the chaebol led the rapid economic growth of Korea. However, the concentration of economic power in the chaebol deepened in both the product and financial markets. According to Choi (2007), this concentration of economic power appeared not only in the economic sector, but in the non-economic sector as well. For instance, links between politics and big business broke the economic system.

Table 7 Real assets of the chaebol (in percentage)

\begin{tabular}{lccccc}
\hline & $\mathbf{1 9 8 7}(\%)$ & $\mathbf{1 9 9 2}(\%)$ & $\mathbf{1 9 9 7}(\%)$ & $\mathbf{1 9 9 8}(\%)$ & $\mathbf{2 0 0 2}(\%)$ \\
\hline Inventories & 26.6 & 22.4 & 19.2 & 14.3 & 12.1 \\
Tangible assets & 72.3 & 76.9 & 80.0 & 84.6 & 82.6 \\
Land & 9.0 & 12.1 & 14.2 & 19.2 & 19.9 \\
Buildings, structures, construction in progress & 27.6 & 29.0 & 34.8 & 28.4 & 27.9 \\
Machinery & 21.0 & 25.1 & 21.7 & 27.4 & 23.8 \\
Transportation equipment & 10.0 & 6.8 & 5.2 & 5.6 & 7.0 \\
Other tangible assets & 4.6 & 3.9 & 4.2 & 4.0 & 3.9 \\
Intangible assets & 1.1 & 0.7 & 0.7 & 1.1 & 5.4 \\
Total real as sets & 100.0 & 100.0 & 100.0 & 100.0 & 100.0 \\
\hline
\end{tabular}


Though the government imposed restraints on the chaebol in the late 1980s, research demonstrating a decrease in the chaebol's concentration of economic power is rare.

In this paper, financial transactions of the institutional sectors $\left(Y\right.$ and $\left.Y^{*}\right)$ are estimated by applying an input-output analysis method. Fund-raising from banks and other financial institutions increased, while fund-raising from the corporate sector decreased for other private corporations. However, in the financial structure of the chaebol, we found that fund-raising from other private corporations increased, not that funds from banks decreased. On the other hand, the deposits of other private corporations in asset portfolios grew. Moreover, the fund-employment share to banks and other financial institutions ${ }^{4}$ increased. In other words, the financial structure of small- and medium-sized corporations deeply depends on the financial sector. In contrast, for the chaebol, the fund-employment share to banks was sharply reduced, while other financial institutions and other private corporations appeared to expand in the chaebol's asset portfolios. In addition, chaebol investment in securities increased drastically, accounting for about $50 \%$ of the financial assets of the chaebol (table E) in 2002. In other words, the chaebol carried out not only the corporations' original role of raising funds from other institutional sectors and producing, but also making investments as is done in the financial sector. To sum up, it seems that the chaebol's concentration of economic power in the financial market and their influence on small- and medium-sized corporations were much stronger.

We also examined the four indices using a Leontief inverse matrix. We found that the power-of-dispersion indices in the asset-oriented system differed between the chaebol and other private corporations. Between 1987 and 2002, the former increased, while the latter decreased. In the case of the chaebol, excess liabilities were reduced, while investments in financial assets rose. This tendency increased the power-of-dispersion index in the asset-oriented system. Our previous research found that this index was decreased in the Korean private corporate sector. However, the index of the chaebol was increased when the private corporate sector was divided into the chaebol and small-/mediumsized corporations in the paper. Such results appear to explain the chaebol's increased concentration of economic power in the Korean financial market.

Acknowledgements

Not applicable.

Competing interests

Not applicable.

Availability of data and materials

The Bank of Korea, Economic Statistics System (http://ecos.bok.or.kr/).

Consent for publication

Not applicable.

Ethics approval and consent to participate

Not applicable.

Funding

Not applicable.

${ }^{4}$ We can speculate that the financial sector requires a secured loan or a compensating balance (an amount a lending institution requires a borrower to leave on deposit during the term of a loan) to small- and medium-sized enterprises. 


\section{Publisher's Note}

Springer Nature remains neutral with regard to jurisdictional claims in published maps and institutional affiliations.

Received: 30 May 2017 Accepted: 15 August 2017

Published online: 18 September 2017

\section{References}

Amsden AH (1989) Asia's next giant: South Korea and late industrialization. Oxford University, London

Amsden AH, Euh YD (1992) South Korea's 1980s financial reforms: good-bye financial repression (Maybe) hello new institutional restraints. World Dev 21(3):379-390

Choi J-P (2007) Failed chaebol policies. Haenam Publishing House, Changsha (in Korean)

Copeland MA (1952) A study of money flow in the United States. NBER, Cambridge

Jones LR, Sakong I (1980) Government, business, and entrepreneurship in economic development: the Korean case. Havard Unversity Press, Cambridge

Kim YT (2000) Chaebol and power. People of Fresh Mind Publishing Co., Ltd, Dubuque (in Korean)

Kim J (2013) The comparative analysis of flow-of-funds in Korea and Japan: using the power of liability and asset dispersion indices input-output analysis. Innov I O Tech 21(3):59-76 (in Japanese)

Kim J (2016) Inter Industry Analysis and Monetary Policy Evaluations in the Korean Flow of Funds Accounts, IDE Discussion Paper, No. 619

Krueger AO, Yoo J (2002) Chaebol capitalism and the currency-financial crisis in Korea. In: Krueger AO, Jungho Y (eds) Preventing currency crises in emerging markets. University of Chicago Press, Chicago, pp 601-661

Lee J-H (2002) Reformation of the chaebol and economic democracy, democracy over corporations and corporate governance structure. edited by Institute of Democratic Society, pp 59-76, Baeksansoedang (in Korean)

Lee Y-H (2005) The capital structure and financing of Korean chaebols (The chaebol of Korea 2). Nanam Publishing House, Seoul (in Korean)

Lee CH, Keun L, Kangkook L (2002) Chaebol, financial liberalization, and economic crisis: transformation of quasi-internal organization in Korea. Asian Econ J 16(1):17-35

Nishiyama S (1991) An interindustry study of flow-of-funds accounts in Japan. Ehime Econ J 11(2):27-40 (in Japanese)

The Bank of Korea (2001) An explication of flow of funds accounts. The Bank of Korea (in Korean)

Tsujimura K, Masako M (2002a) European financial integration in the perspective of global flow of funds. KEO Discussion Paper, No. 72

Tsujimura K, Masako M (2002b) Flow-of-funds analysis-basic technique and policy evaluation. Keio University Publication, Tokyo (in Japanese)

Tsujimura K, Mizoshita M (2003) Asset-liability-matrix analysis derived from the flow-of-funds accounts: the Bank of Japan's quantitative monetary policy examined. Econ Syst Res 15(1):51-67

\section{Submit your manuscript to a SpringerOpen ${ }^{\circ}$ journal and benefit from:}

- Convenient online submission

Rigorous peer review

- Open access: articles freely available online

- High visibility within the field

- Retaining the copyright to your article

Submit your next manuscript at $\boldsymbol{\Delta}$ springeropen.com 